\title{
ROMANIAN IN VITRO BRYOPHYTE COLLECTION AND ITS ROLE FOR CONSERVATION
}

\section{COGĂLNICEANU Gina*}

\begin{abstract}
The in vitro bryophyte collection of the Institute of Biology Bucharest represents the first initiative at national level for bryophyte ex-situ conservation using biotechnological techniques. Micro-propagation and medium-term storage protocols have been developed for 25 bryophyte species of both liverworts and mosses. The collection serves for conservation as well as for research and biotechnological purposes.
\end{abstract}

Key words: bryophytes, in vitro collection, ex-situ conservation, axenic micro-propagation

\section{General context and aim}

The biodiversity crisis is considered one of the major current global problems. The present rates of species extinction are estimated to be $100-1,000$ times greater than the natural (pre-human) rates (Chapin III et al. 2000). The growing concern for the loss of plant diversity has resulted in the development of global, regional, and national conservation strategies (e.g., Global Strategy for Plant Conservation 2002, European Strategy for Plant Conservation 2008). Among other measures, ex-situ conservation has gained an increased importance under the pressure of unpredictable climate events (Leemans \& Eickhout 2004).

The hornworts (phylum Anthocerophyta), liverworts (phylum Marchantiophyta, also known as Hepatophyta) and mosses (phylum Bryophyta, also known as Musci) are called in this paper by the generic term bryophytes (no taxonomic status).

Bryophytes are the second largest group of plants, including 15,000 (Gradstein et al. 2001) - 25,000 species (Crum 2001), after Magnoliophyta with 350,000 species. They are found in all types of habitat that support photosynthesis (Glime 2007). Their ecological role is significant for carbon and nutrient cycle, water retention and water availability (Vanderpoorten \& Goffinet 2009). The bryophytes of Europe are both very diverse and very threatened $(24.1 \%)$, requiring concrete and effective conservation measures (Hodgetts 1996, Hallingbäck \& Hodgetts 2000).

In Romania, bryophytes represent $20.6 \%$ of the total number of plant species (3,759 cormophyte species according to Ciocârlan, 2009). Of the 979 species of bryophytes included in the National Checklist and Red List (Ştefănuț \& Goia 2012), 374 species $(38 \%)$ are considered threatened. Only 10 bryophyte species are included in the national legislation as threatened and requiring protection $(2.67 \%)$. No national

* Institute of Biology Bucharest of Romanian Academy, Department of Plant and Animal Cytobiology, 296 Splaiul Independenței, 060031-Bucharest, P.O. Box 56-53, Romania,email: gina.cogalniceanu@ibiol.ro 
ex-situ conservation program for endangered plant species includes bryophytes, their conservation being limited only to priority species in protected areas listed in the Habitats Directive (Rojanschi et al. 2011). The first Romanian initiative for bryophyte conservation using biotechnologies was started as part of a project funded by the Romanian Academy devoted to conservation of endangered plants. In this context, we started a bryophyte in vitro collection for conservation, basic research and biotechnological purposes. Our objective was to develop reproducible and efficient protocols for bryophytes collecting, micro-propagation and storage for short, medium and long term, as requested by the European Strategy for Plant Conservation 2008 2014 (Anonymous 2008).

\section{Working principles}

The in vitro culture methodologies were tested previously on common bryophyte species. The advantages of this approach are threefold: (i) collecting common species for culture initiation poses no threat to their populations, (ii) developing protocols for species that are not presently under threat represents an excellent proactive approach in case the target species become endangered, and (iii) allows comparative studies on threatened/non-threatened species. Bryophyte samples were collected mostly from less human impacted areas.

We introduced in in vitro culture even species not currently requiring protection, asserting that under unpredictable global changes the decline and extinction rates will intensify and conservation measures have to be applied in a proactive manner (Cogălniceanu \& Cogălniceanu 2010).

\section{Collecting requirements}

We consider that collaboration with a bryophyte specialist is essential for the taxonomic confirmation in two critical moments: firstly, at the collection time, and secondly, after the species were included in the vitroculture. The optimal period for collection is when the capsules of the sporophytes are mature. In rare and/or protected species only small samples of plant tissues should be collected. Separating the talli from spore capsules in different collecting containers is indicated for further identification and sterilization.

\section{cultivation}

In vitro multiplication protocol - specific problems related to in vitro

The most difficult problem we faced in introducing bryophytes in in vitro culture was sterilization. Due to their structural and functional characteristics (including the presence of fungal and/or bacterial endophytes), the methodologies used for sterilization in cormophyta are not adequate for bryophytes. The most efficient sterilizing agent proved to be sodium dichloroisocyanurate (NaDCC), used in concentration of $0.5 \%$ $1 \%(\mathrm{w} / \mathrm{v})$ for $1-6 \mathrm{~min}$. We have started the cultures either from spores or from gametophyte thalli fragments, grown on solid minimal nutritive medium Knop (1865), solidified with $2 \mathrm{~g} / \mathrm{l}$ gelrite or $7 \mathrm{~g} / \mathrm{l}$ agar, but never with sucrose or other carbohydrate source, bryophytes being in vitro photoautotrophs (Duckett et al. 2004). Any attempt of cultivation of liverworts or mosses on complex nutritional media (supplemented with vitamins, phytohormones, or carbohydrates, such as Gamborg (1968) or Murashige- 
Skoog (1962) formula) failed due to the rapid proliferation of endophyte microorganisms (Cogălniceanu, unpubl.). Another specific bryophyte culture demand is the mild temperature requirements $\left(18-20^{\circ} \mathrm{C}\right.$ ) (Vujičić et al. 2010). Our bryophyte cultures were grown at $22 \pm 2^{\circ} \mathrm{C}$, with a 16 hours light (2000 lux light intensity)/8 hours dark photoperiod. Cultures were transferred on fresh medium every 4 weeks.

\section{Medium and long-term conservation}

A problem in axenic plant collections is their persistence for medium and long term, without contamination and/or spontaneous genetic alteration (somaclonal variations), and with low costs. We developed a method of medium term conservation of bryophytes by growing cell cultures at low temperatures $\left(10^{\circ} \mathrm{C}\right)$ and low illumination (1000 lux) on minimal nutritive medium (Knop 1865). In such conditions, transfers on fresh media were made at 3-6 months.

A long-term conservation method we tested was the cryopreservation of bryophyte germplasm. Cryopreservation has obvious advantages over the in vitro storage in terms of space saving, improved phytosanitation and diminished genetic instability. The suitability of bryophytes for cryopreservation is sustained also by their capacity for revival from anabiosis, and their constitutive extreme tolerance to desiccation (Proctor 2000, Oliver et al. 2005, Glime 2007). Experiments are currently underway.

\section{Bryophytes as model systems in fundamental research}

On the base of their morphological, physiological, genetic and life history characteristics, bryophytes can be used as simple model systems for studying different aspects of cytodifferentiation and morphogenesis, as well as the evolution of the more complex features in the higher plants. For example, we found that the plasmodesmata peculiarities in Sphagnum magellanicum support a cellular specialization in symplastic transport. The hyaline cells formation and secondary wall patterning, the orientation of microtubules associated with this process resembled ultrastructural development in tracheary elements of the higher plants (Brezeanu et al. 2009). Electronomicroscopical analysis of the in vitro propagated gametophyte of Bucegia romanica showed that the experimental conditions did not induce ultrastructural abnormalities, the in vitro system being suitable for conservative purposes (Brezeanu et al. 2008).

\section{Results of in vitro cultivation}

During 2005-2010 we developed and validated micro-propagation protocols for 25 species of bryophytes (Fig. 1) that were maintained in in vitro culture for variable periods of time (Cogălniceanu et al. 2006, Cogălniceanu \& Stoiculescu 2007): Asterella gracilis (F.Weber) Underw., Athalamia hyalina (Sommert.) Hatt,, Atrichum undulatum (Hedw.) P.Beauv., Bucegia romanica Radian, Bartramia halleriana Hedw., Bazzania tricrenata (Wahlenb.) Lindb., Calliergonella cuspidata (Hedw.) Loeske, Conocephalum conicum (L.) Dumort, Cratoneurum sp., Dicranum sp., Funaria hygrometrica Hedw., Hylocomium sp., Leucodon sciuroides (Hedw.) Schwägr., Marchantia polymorpha L., Mnium sp., Philonotis sp., Plagiomnium sp., Polytrichum longisetum Brid., Porella platyphylla (L.) Pfeiff., Pottia sp., Preissia qudrata (Scop.) Nees, Reboulia hemisphaerica (L.) Raddi, Sauteria alpine (Nees) Nees, Thamnobryum sp., and Tortula 
muralis Hedw. Our in vitro bryophyte collection currently holds a number of six species, of both liverworts and mosses (Table 1).

Table 1

The 2013 bryophyte in vitro collection at the Institute of Biology Bucharest. The IUCN (2011) Red List categories: VU (Vulnerabile), LC (Least Concern).

\begin{tabular}{clcc}
\hline \multicolumn{1}{c}{ Phylum } & \multicolumn{1}{c}{ Species } & $\begin{array}{c}\text { IUCN (2011) } \\
\text { Red List } \\
\text { categories }\end{array}$ & $\begin{array}{c}\text { Year of } \\
\text { introduction in } \\
\text { culture }\end{array}$ \\
\hline Marchantiophyta & $\begin{array}{c}\text { Bucegia romanica } \text { Radian } \\
\text { Conocephalum conicum } \text { (L.) Dumort }\end{array}$ & VU & 2005 \\
& Marchantia polymorpha L. & LC & 2006 \\
Bryophyta & Reboulia hemisphaerica (L.) Raddi & LC & 2005 \\
& Atrichum undulatum (Hedw.) & LC & 2005 \\
& P.Beauv. & & 2006 \\
& Bartramia halleriana Hedw. & LC & 2006 \\
\hline
\end{tabular}

\section{Further directions of research}

Bryophytes contain numerous potentially useful compounds, including oligosaccharides, polysaccharides, sugar alcohols, amino acids, fatty acids, aliphatic compounds, phenylquinones, aromatic and phenolic substances. Traditional herbal medicines of China (Hu 1987), India (Banerjee 1974) and Native Americans (University of Michigan, Dearborn, 2003) include bryophytes. A direction for further research in our lab is the investigation of bryophyte potential for pharmaceutical, cosmetic or agricultural use. Species that we have already introduced in in vitro cultures are cited in scientific literature for: antimicrobial (Marchanthia, Polytrichum, Dicranum, Conocephalum, Reboulia), anti-leukemic (Marchanthia), anti-tumor (Conocephalum, Marchanthia, Porella), anti-inflammatory (Bryum, Polytrichum), diuretic, laxative and haemostatic (Polytrichum) activity (Glime 2007). For example, we measured the antioxidant activity of the thalus extract from B. romanica, $M$. polymorpha, C. conicum and $B$. halleriana. We found that the antioxidant activity is highly correlated with their polyphenol and flavonoid content which we have determined for each species (Mitoi \& Cogălniceanu, unpubl.). Notable is $B$. halleriana with strong antioxidant and reducing activity, comparable to that of the higher plants. 

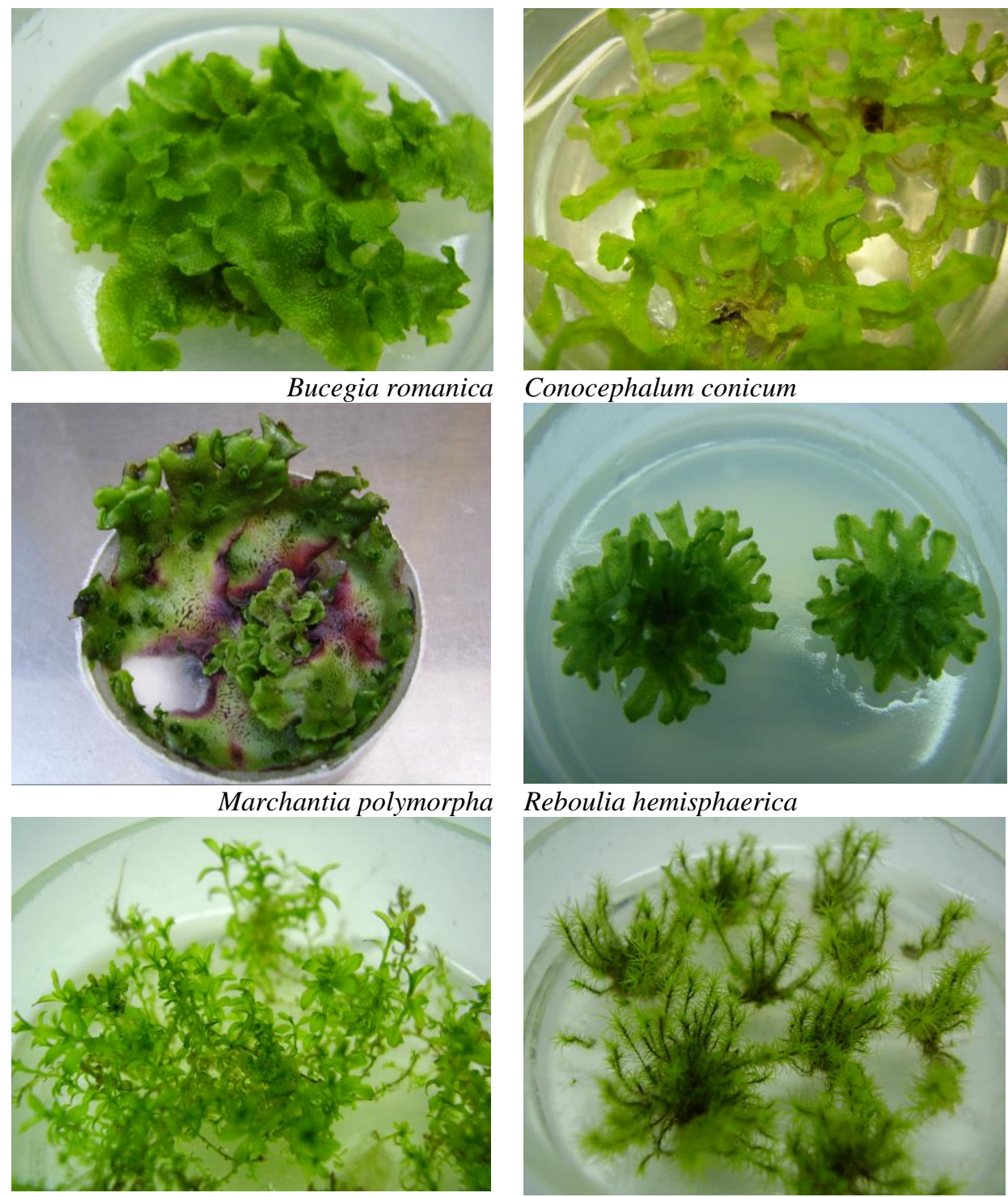

Atrichum undulatum

Bartramia halleriana

Fig. 1. Bryophyte taxa from the in vitro collection of the Institute of Biology Bucharest. 


\section{Conclusions}

Despite of number of difficulties around developing in vitro cultures of bryophytes, species specific protocols for micro-propagation and medium-term storage have been developed to enable the creation of such in vitro cultures for conservation as well as biotechnological purposes.

Acknowledgements: The study was funded by the project no. RO1567IBB06/2005-2013 from the Institute of Biology Bucharest, The Romanian Academy. Special thanks to dr. Ştefănuț Sorin and dr. Dihoru Gheorghe for species identification and to dr. Ştefănuț Sorin and dr. Cogălniceanu Dan for collecting bryophyte samples.

\section{References}

Anonymous (2002). Global Strategy for Plant Conservation, COP VI/9. Retrieved March, 2014, from: http://biodiv.org/decisions/default.asp?dec=VI/9

Anonymous (2008). The European Strategy for Plant Conservation 2008-2014.

Retrieved March, 2014, from: http://www.plantlife.org.uk/uploads/documents/New_European_Strategy_for_Pl ant_Conservation_\%282008-2014\%29.pdf

Anonymous (2011). IUCN STANDARDS AND PETITIONS SUBCOMMITTEE: Guidelines for Using the IUCN Red List Categories and Criteria. Version 9.0. Retrieved March, 2014, from: http://www.iucnredlist.org/documents/RedListGuidelines.pdf

Banerjee, R.D. (1974). Studies on antibiotic activity of bryophytes and pteridophytes. Ph.D. thesis. University of Kaliany. Kaliany, India.

Brezeanu, A., Cogălniceanu, G. \& Stoiculescu R. (2008). Ultrastructural characterization of the in vitro gametophyte of Bucegia romanica Radian - a rare liverwort. Rom. J. Biol.- Plant Biol., 53(2), 49-61.

Brezeanu, A., Cogălniceanu, G.\& Mihai, R. (2009). Studying cell biology of bryophytes. Biotechnol. Biotech. Eq., 23, 467-468, Special Edition/on-line.

Chapin III, F.S., Zavaleta, E.S., Eviner, V.T., Naylor, R.L., Vitousek, P.M., Reynolds, H.L., Hooper, D.U., Lavorel, S., Sala, O.E., Hobbie, S.E., Mack, M.C. \& Diaz, S. (2000). Consequences of changing biodiversity. Nature, 405, 234-242.

Ciocârlan, V. (2009). Flora ilustrată a României. Bucureşti: Edit. Ceres. 1149 pp.

Cogălniceanu, D. \& Cogălniceanu, G. (2010). An enlarged European Union challenges priority settings in conservation. Biodivers. Conserv., 19(5), 1471-1483.

Cogălniceanu, G. \& Stoiculescu, R. (2007). Particularități privind culturile in vitro la briofite. In D. Cachiță-Cosma (ed.). Micropropagarea Speciilor Vegetale, Lucrările celui de-al XV-lea Simpozion Național de Culturi de Țesuturi şi Celule Vegetale, Iaşi. 2006. Cluj-Napoca: Edit. Risoprint.

Cogălniceanu, G., Stoiculescu, R.\& Ştefănut,, S. (2006). Conservarea in vitro la briofite. In D. Cachiță-Cosma \& C.Sand (eds.). Conservarea vitroculturilor vegetale. Lucrările celui de-al XIV-lea Simpozion Național de Culturi de Țesuturi şi Celule Vegetale. Sibiu. 2005. Sibiu: Edit. Alma Mater.

Crum, H. (2001). Structural Diversity in Bryophytes. University of Michigan Herbarium, Ann. Arbor.

Duckett, J.G., Burch, J., Fletcher, P.W., Matcham, H.W., Read, D.J., Russell, A.J. \& Pressel S. (2004). In vitro cultivation of bryophytes: a review of practicalities, problems, progress and promise. J. Bryol., 26, 3-20. 
Gamborg, O.L., Miller, R.A. \& Ojima, K. (1968). Nutrient requirements of suspension cultures of soybean root cells. Exp. Cell Res. 50: 151-158.

Glime, J.M. (2007). Bryophyte ecology. Retrieved March, 2014, from: http://www.bryoecol.mtu.edu/

Gradstein, S.R., Churchill, S.P. \& Salazar, A.N. (2001). Guide to the Bryophytes of Tropical America. Mem. N. Y. Bot. Gard., 86, 1-577.

Hallingbäck, T. \& Hodgetts, N. (compilers) (2000). Mosses, Liverworts, and Hornworts. Status Survey and Conservation Action Plan for Bryophytes. IUCN/SSC Bryophyte Specialist Group. IUCN, Gland, Switzerland and Cambridge, UK.

Hodgetts, N. 1996. Threatened bryophytes in Europe. Anales Inst. Biol. Univ. Nac. Autón. México, Ser. Bot., 67(1), 183-200.

Hu, R. (1987). Bryology. Beijing: Higher Education Press.

Knop, W. (1865). Quantitative Untersuchungen über die Ernahrungsprozesse der Pflanzen. Landwirtsch. Vers. Stn. ,7, 93-107.

Leemans, R. \& Eickhout, B. (2004). Another reason for concern: regional and global impacts on ecosystems for different levels of climate change. Global Environ. Chang., 14, 219-228.

Murashige, T. \& Skoog, F. (1962). A revised medium for rapid growth and bio-assays with tobacco tissue cultures. Physiol. Plantarum., 15, 473-497.

Oliver, M.J., Veltren, J., Mishler, B.D. (2005). Desiccation tolerance in bryophytes: a reflection of the primitive strategy for plant survival in dehydrating habitats? Integr. Comp. Biol., 45(5), 788-799.

Proctor, M.C.F. (2000). The bryophyte paradox: tolerance of desiccation, evasion of drought. Plant Ecol., 151, 41-49.

Rojanschi, V., Ştefănescu, R., Pop, D.A. \& Săvulescu, A.R. (2011). Strategie națională şi Plan de acțiune privind conservarea biodiversității în România pentru decada 2011-2020. Bucureşti: Tipografia Digital Advertising. 207 pp.

Ştefănuț, S. \& Goia, I. (2012). Checklist and Red List of Bryophytes of Romania. Nova Hedwigia, 95(1-2), 59-104.

University of Michigan, Dearborn. (2003). Native American Etnobotany, A database of foods, drugs, dyes and fibres of native American peoples, derived from plants. Retrieved February 4, 2014, from http://herb.umd.umich.edu

Vanderpoorten, A. \& Goffinet, B. (2009). Introduction to bryophytes, Cambridge: Cambridge University Press. 328 pp.

Vujičić, M., Cvetić, T., Sabovljević, A. \& Sabovljević, M. (2010). Axenically culturing the Bryophytes: a case study of the liverworth Marchantia polymorpha L. ssp. ruderalis Bischl. \& Boisselier (Marchantiophyta, Marchantiaceae). Kragujevac J. Sci., 32, 73-81. 